\title{
Feline Oral Squamous Cell Carcinoma
}

National Cancer Institute

\section{Source}

National Cancer Institute. Feline Oral Squamous Cell Carcinoma. NCI Thesaurus. Code C132824.

Oral squamous cell carcinoma that occurs in a cat. 